NASA/TM-2006-214111

\title{
Simulated Data for High Temperature Composite Design
}

Christos C. Chamis

Glenn Research Center, Cleveland, Ohio

Galib H. Abumeri

QSS Group, Inc., Cleveland, Ohio 
Since its founding, NASA has been dedicated to the advancement of aeronautics and space science. The NASA Scientific and Technical Information (STI) Program Office plays a key part in helping NASA maintain this important role.

The NASA STI Program Office is operated by Langley Research Center, the Lead Center for NASA's scientific and technical information. The NASA STI Program Office provides access to the NASA STI Database, the largest collection of aeronautical and space science STI in the world. The Program Office is also NASA's institutional mechanism for disseminating the results of its research and development activities. These results are published by NASA in the NASA STI Report Series, which includes the following report types:

- $\quad$ TECHNICAL PUBLICATION. Reports of completed research or a major significant phase of research that present the results of NASA programs and include extensive data or theoretical analysis. Includes compilations of significant scientific and technical data and information deemed to be of continuing reference value. NASA's counterpart of peerreviewed formal professional papers but has less stringent limitations on manuscript length and extent of graphic presentations.

- TECHNICAL MEMORANDUM. Scientific and technical findings that are preliminary or of specialized interest, e.g., quick release reports, working papers, and bibliographies that contain minimal annotation. Does not contain extensive analysis.

- CONTRACTOR REPORT. Scientific and technical findings by NASA-sponsored contractors and grantees.
- CONFERENCE PUBLICATION. Collected papers from scientific and technical conferences, symposia, seminars, or other meetings sponsored or cosponsored by NASA.

- SPECIAL PUBLICATION. Scientific, technical, or historical information from NASA programs, projects, and missions, often concerned with subjects having substantial public interest.

- TECHNICAL TRANSLATION. Englishlanguage translations of foreign scientific and technical material pertinent to NASA's mission.

Specialized services that complement the STI Program Office's diverse offerings include creating custom thesauri, building customized databases, organizing and publishing research results ... even providing videos.

For more information about the NASA STI Program Office, see the following:

- Access the NASA STI Program Home Page at http://www.sti.nasa.gov

- E-mail your question via the Internet to help@sti.nasa.gov

- Fax your question to the NASA Access Help Desk at 301-621-0134

- Telephone the NASA Access Help Desk at 301-621-0390

- Write to:

NASA Access Help Desk

NASA Center for AeroSpace Information 7121 Standard Drive

Hanover, MD 21076 
NASA/TM-2006-214111

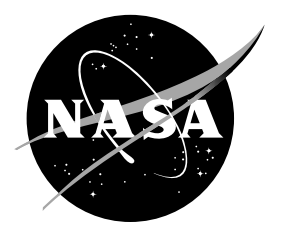

\section{Simulated Data for High Temperature Composite Design}

Christos C. Chamis

Glenn Research Center, Cleveland, Ohio

Galib H. Abumeri

QSS Group, Inc., Cleveland, Ohio

National Aeronautics and

Space Administration

Glenn Research Center 
Trade names or manufacturers' names are used in this report for identification only. This usage does not constitute an official endorsement, either expressed or implied, by the National Aeronautics and Space Administration.

Available from

NASA Center for Aerospace Information 7121 Standard Drive

Hanover, MD 21076
National Technical Information Service 5285 Port Royal Road Springfield, VA 22100

Available electronically at http:/ /gltrs.grc.nasa.gov 


\title{
Simulated Data for High Temperature Composite Design
}

\author{
Christos C. Chamis \\ National Aeronautics and Space Administration \\ Glenn Research Center \\ Cleveland, Ohio 44135 \\ Galib H. Abumeri \\ QSS Group, Inc. \\ Cleveland, Ohio 44135
}

\begin{abstract}
The paper describes an effective formal method that can be used to simulate design properties for composites that is inclusive of all the effects that influence those properties. This effective simulation method is integrated computer codes that include composite micromechanics, composite macromechanics, laminate theory, structural analysis, and multi-factor interaction model. Demonstration of the method includes sample examples for static, thermal, and fracture reliability for a unidirectional metal matrix composite as well as rupture strength and fatigue strength for a high temperature super alloy. Typical results obtained for a unidirectional composite show that the thermal properties are more sensitive to internal local damage, the longitudinal properties degrade slowly with temperature, the transverse and shear properties degrade rapidly with temperature as do rupture strength and fatigue strength for super alloys.
\end{abstract}

\section{Introduction}

As candidate materials for advanced high temperature aerospace structures, metal matrix composites (MMCs) have been the subject of considerable interest and extensive research. With concurrent advances in processing, fabrication, and experimental mechanics, MMCs will increasingly be used as structural materials for advanced propulsion systems. The extreme temperatures and stresses of these propulsion systems create a hostile environment for the composite to withstand. Therefore, the analysis and design of these materials are critically important and require the use of mathematical models to predict thermal and mechanical behavior. One such model is the computer code METCAN (METal matrix Composite ANalyzer, reference 1) developed at NASA Glenn Research Center.

This paper presents the mechanical and thermal properties of a unidirectional composite from silicon carbide (SiC)/titanium (Ti6) MMC as computationally simulated by METCAN from constituents properties as described subsequently. It provides results for one fiber volume ratio at a range of temperatures in graphical form. These plots include stress-strain, elastic and shear moduli, Poisson's ratio, thermal expansion, and thermal conductivity. Similar information can be readily generated for: 1) other loading condition, 2) other composites, and 3) other service conditions. A list of symbols used is included in the appendix where a short table of conversion factors from customary units to SI units is also included.

\section{Background}

METCAN has the capability to predict many aspects of high temperature MMCs by using room temperature constituent properties. METCAN's integrated approach is illustrated in figure 1 as a cyclic arrangement that defines the computational methodology for each load increment. As can be seen from the figure, this predictive capability consists of several computational modules encompassing the material nonlinear behavior (bottom), composite mechanics (sides), and the finite element analysis of structural components (top). Material nonlinearity is treated at the constituent level, where the current material model, namely the Multi-Factor Interaction Model (MFIM), figure 2, describes a time-temperature-stress 


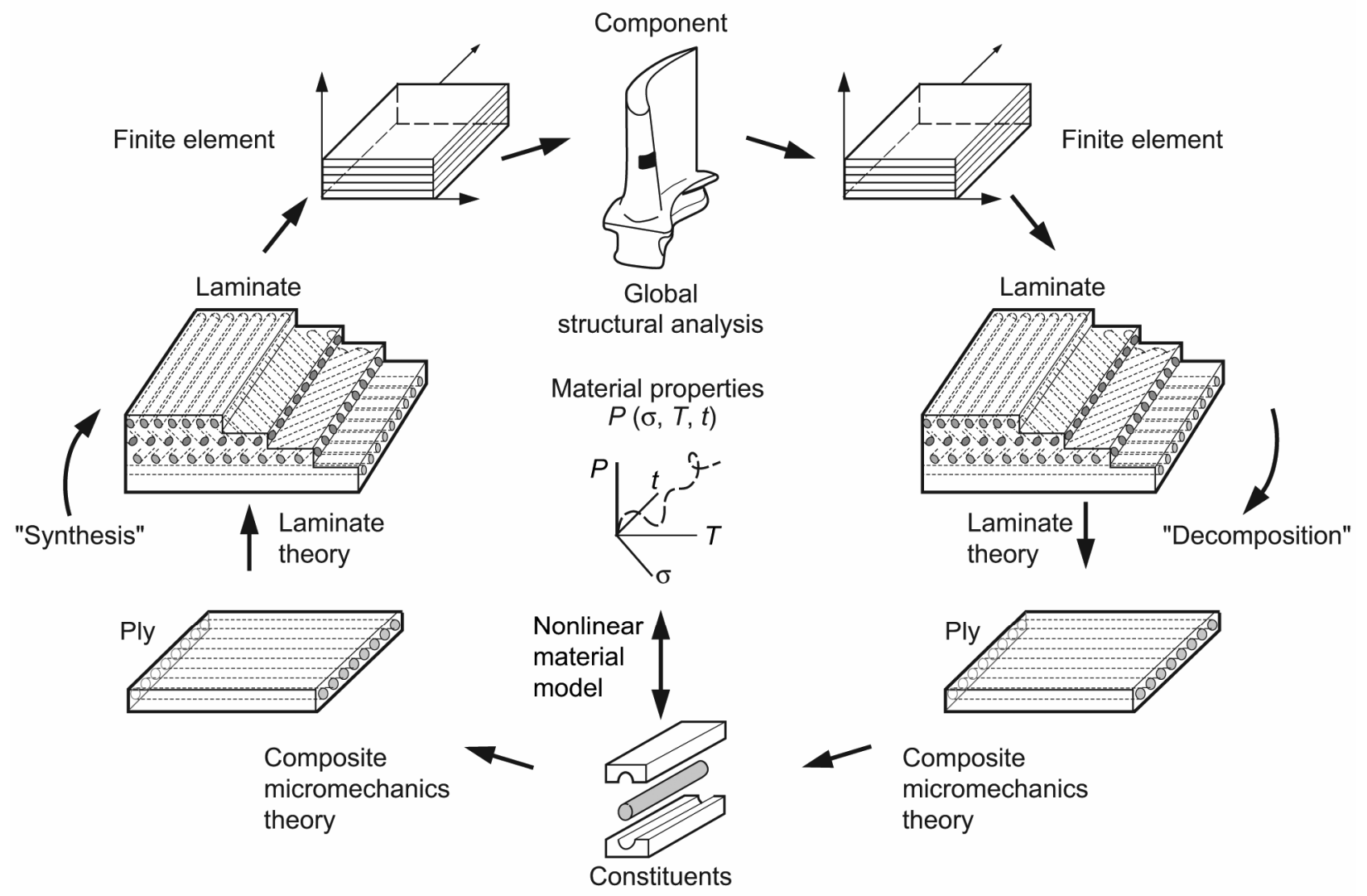

Figure 1.-Integrated approach to metal-matrix composite analysis.

$$
\begin{aligned}
& \frac{P}{P_{0}}=\left[\frac{T_{F}-T}{T_{F}-T_{0}}\right]^{n}\left[\frac{S_{F}-\sigma}{S_{F}-\sigma_{0}}\right]^{m}\left[\frac{\dot{S}_{F}-\dot{\sigma}}{\dot{S}_{F}-\dot{\sigma}_{0}}\right]^{l}\left[\frac{\dot{T}_{F}-\dot{T}}{\dot{T}_{F}-\dot{T}_{0}}\right]^{k}\left[\frac{R_{F}-R}{R_{F}-R_{0}}\right]^{p} \ldots . . \\
& \cdots \cdot\left[\frac{N_{M F}-N_{M}}{N_{M F}-N_{M 0}}\right]^{q}\left[\frac{N_{T F}-N_{T}}{N_{T F}-N_{T 0}}\right]^{r}\left[\frac{T_{F}-T}{T_{F}-T_{0}}\right]^{s} \ldots \ldots
\end{aligned}
$$

Rationale:

- Gradual effects during most range, rapidly degrading near final stages

- Representative of the in situ behavior for fiber, matrix interphase, coating

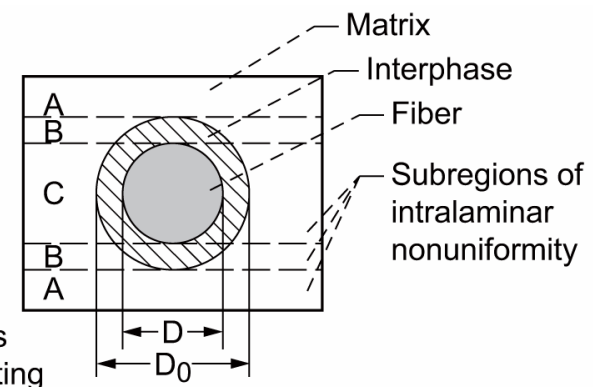

- Introduction of primitive variables (PV)

- Consistent in situ representation of all constituent properties in terms of PV

- Room temperature values for reference properties

- Continuous interphase growth

- Simultaneous interaction of all primitive variables

- Adaptability to new materials

- Amenable to verification inclusive of all properties

- Readily adaptable to incremental computational simulation

Notations: $P$ - property; $T$ - temperature; $S$ - strength; $R$ - metallurgical reaction; $N$ - number of cycles; $T$ - time; Over dot - rate; subscripts: 0 - reference; $F$ - final; $m$ - mechanical; $t$ - thermal

Figure 2.-Assumed multi-factor interaction relationship to represent the various factors which influence in situ constituent materials behavior. 
dependence of a constituent's mechanical and thermal properties at any point in its material history (ref. 2). Characteristic properties of the composite are calculated from the instantaneous constituent properties using composite mechanics. This synthesis results in a point description of equivalent pseudohomogeneous properties for the composite.

Naturally, some assumptions have been made in the development of this code. The MFIM utilizes a large number of exponents that, ideally, have been calculated from experimental data. When reliable experimental data is unavailable, default values are used. These values were established from studies conducted on other MMCs (ref. 3). The exponents used in this study are summarized in table 1. Secondly, the Ti6 matrix melting temperature in METCAN was given a value close to the consolidation temperature. Since the matrix has no remaining strength at the consolidation temperature and METCAN must simulate this behavior, the actual melting temperature was replaced with one that was slightly higher than the consolidation temperature. The room temperature constituent properties used are listed in table 2. Verification of METCAN (comparisons with experimental data) is described in reference 4.

Additionally, a modification was made in METCAN for this particular task. Since progressive failure of the composite was not a consideration, the method of stopping the program after failure was altered slightly. Normally, when failure occurs in one region, the load is channeled into the remaining regions until the composite suffers a complete fracture. For this study, once failure takes place in a critical region, the simulation is stopped and the material properties for that strain are set at zero. Under a longitudinal load, this critical region is defined as the fiber. For transverse and shear loads, the determining sector is the micro-region A of the matrix (fig. 2).

TABLE 1.-METCAN EXPONENTS

\begin{tabular}{|c|c|c|c|c|c|}
\hline \multirow[b]{2}{*}{$\operatorname{Exp}$} & \multirow[b]{2}{*}{$\begin{array}{c}\text { Array } \\
\text { Location }\end{array}$} & \multirow[b]{2}{*}{ Property } & \multirow[b]{2}{*}{$\begin{array}{c}\text { Determining } \\
\text { Property }\end{array}$} & \multicolumn{2}{|c|}{ Values } \\
\hline & & & & $\mathrm{SiC}$ & Ti6 \\
\hline$\ell$ & 2 & Modulus & $\dot{\sigma}$ & 0.25 & 0.50 \\
\hline $\mathrm{m}$ & 3 & Modulus & $\sigma$ & 0.25 & 0.50 \\
\hline $\mathrm{n}$ & 4 & Modulus & $\mathrm{T}$ & 0.25 & 0.587 \\
\hline$\ell$ & 5 & Strength & $\dot{\sigma}$ & 0.25 & 0.50 \\
\hline $\mathrm{m}$ & 6 & Strength & $\sigma$ & 0.0 & 0.0 \\
\hline $\mathrm{n}$ & 7 & Strength & $\mathrm{T}$ & 0.25 & 0.902 \\
\hline$\ell$ & 8 & Poisson's Ratio & $\dot{\sigma}$ & 0.25 & 0.50 \\
\hline $\mathrm{m}$ & 9 & Poisson's Ratio & $\sigma$ & 0.25 & 0.50 \\
\hline $\mathrm{n}$ & 10 & Poisson's Ratio & $\mathrm{T}$ & 0.25 & 0.50 \\
\hline$\ell$ & 14 & $\begin{array}{c}\text { Heat } \\
\text { Conductivity }\end{array}$ & $\dot{\sigma}$ & 0.25 & 0.50 \\
\hline $\mathrm{m}$ & 15 & $\begin{array}{c}\text { Heat } \\
\text { Conductivity }\end{array}$ & $\sigma$ & 0.0 & 0.50 \\
\hline $\mathrm{n}$ & 16 & $\begin{array}{c}\text { Heat } \\
\text { Conductivity }\end{array}$ & $\mathrm{T}$ & 0.25 & 0.50 \\
\hline$\ell$ & 17 & CTE & $\dot{\sigma}$ & 0.25 & 0.50 \\
\hline $\mathrm{m}$ & 18 & CTE & $\sigma$ & 0.0 & 0.50 \\
\hline $\mathrm{n}$ & 19 & CTE & $\mathrm{T}$ & 0.25 & 0.037 \\
\hline
\end{tabular}


TABLE 2.-INPUT CONSTITUENT PROPERTIES AT ROOM TEMPERATURE

\begin{tabular}{|c|c|c|c|}
\hline \multicolumn{2}{|c|}{$\begin{array}{c}\text { Fiber: Silicon Carbide on } \\
\text { Aluminum }\end{array}$} & \multicolumn{2}{|c|}{ Matrix: Titanium } \\
\hline $\begin{array}{l}\text { Property } \\
\text { (units) }\end{array}$ & & $\begin{array}{l}\text { Property } \\
\text { (units) }\end{array}$ & Ti6 \\
\hline $\mathrm{N}_{\mathrm{f}}$ & 1 & $\mathrm{~K}_{v}$ & 0.019 \\
\hline $\mathrm{D}_{\mathrm{f}}$ & 0.0102 & $\rho_{\mathrm{m}}\left(\mathrm{lb} / \mathrm{in}^{* *} 3\right)$ & 0.170 \\
\hline$\rho_{\mathrm{f}}\left(\mathrm{lb} / \mathrm{in}^{* *} 3\right)$ & 0.110 & $\mathrm{~T}_{\mathrm{Mm}}(\mathrm{F})$ & 1740 \\
\hline $\mathrm{T}_{\mathrm{Mf}}$ & 4870 & $\mathrm{E}_{\mathrm{m}}(\mathrm{Mpsi})$ & 16.5 \\
\hline $\mathrm{E}_{\mathrm{f} 11}(\mathrm{Mpsi})$ & 62.0 & $v_{\mathrm{m}}$ & 0.300 \\
\hline $\mathrm{E}_{\mathrm{f} 22}(\mathrm{Mpsi})$ & 62.0 & $\alpha_{\mathrm{m}}(\mu \mathrm{in} / \mathrm{in} / \mathrm{F})$ & 5.24 \\
\hline $\mathrm{G}_{\mathrm{f} 12}(\mathrm{Mpsi})$ & 26.1 & $\mathrm{~K}_{\mathrm{m}}(\mathrm{BTU} / \mathrm{hr} / \mathrm{F} / \mathrm{in})$ & 0.390 \\
\hline $\mathrm{G}_{\mathrm{f} 23}(\mathrm{Mpsi})$ & 26.1 & $\mathrm{C}_{\mathrm{m}}(\mathrm{BTU} / \mathrm{lb})$ & 0.120 \\
\hline$v_{f 12}$ & 0.190 & $\mathrm{~S}_{\mathrm{mT}}(\mathrm{ksi})$ & 74.0 \\
\hline$v_{\mathrm{f} 23}$ & 0.190 & $\mathrm{~S}_{\mathrm{mc}}(\mathrm{ksi})$ & 74.0 \\
\hline$\alpha_{\mathrm{f} 11}(\mu \mathrm{in} / \mathrm{in} / \mathrm{F})$ & 2.72 & $\mathrm{~S}_{\mathrm{ms}}(\mathrm{ksi})$ & 74.0 \\
\hline$\alpha_{\mathrm{f} 22}(\mu \mathrm{in} / \mathrm{in} / \mathrm{F})$ & 2.72 & $\varepsilon_{\mathrm{mT}}(\mathrm{in} / \mathrm{in})$ & 44.4 \\
\hline $\mathrm{K}_{\mathrm{f} 11}(\mathrm{BTU} / \mathrm{hr} / \mathrm{F} / \mathrm{in})$ & 0.750 & $\varepsilon_{\mathrm{mc}}(\mathrm{in} / \mathrm{in})$ & 0.350 \\
\hline $\mathrm{K}_{\mathrm{f} 22}(\mathrm{BTU} / \mathrm{hr} / \mathrm{F} / \mathrm{in})$ & 0.750 & $\varepsilon_{\mathrm{mS}}(\mathrm{in} / \mathrm{in})$ & 0.350 \\
\hline $\mathrm{C}_{\mathrm{f}}(\mathrm{BTU} / \mathrm{lb})$ & 0.290 & $\varepsilon_{\mathrm{mTOR}}(\mathrm{in} / \mathrm{in})$ & 0.350 \\
\hline $\mathrm{S}_{\mathrm{flT}}(\mathrm{ksi})$ & 500 & Processing Temperature & $1200^{\circ} \mathrm{F}$ \\
\hline $\mathrm{S}_{\mathrm{flC}}(\mathrm{ksi})$ & 500 & & \\
\hline $\mathrm{S}_{\mathrm{f} 2 \mathrm{~T}}(\mathrm{ksi})$ & 500 & & \\
\hline $\mathrm{S}_{\mathrm{f} 2 \mathrm{C}}(\mathrm{ksi})$ & 500 & & \\
\hline $\mathrm{S}_{\mathrm{f} 12 \mathrm{~s}}(\mathrm{ksi})$ & 300 & & \\
\hline $\mathrm{S}_{\mathrm{f} 23 \mathrm{~s}}(\mathrm{ksi})$ & 300 & & \\
\hline
\end{tabular}

\section{Results and Significances}

For this evaluation, a perfect bond was assumed to exist between the fiber and the matrix. This is reflected by the plots which depict the upper boundaries of the material properties. Fiber volume ratio (FVR) of 0.30 provided a good test for this material. Longitudinal loads were imposed on a unidirectional Silicon Carbide fiber Titanium Matrix (SiC/Ti6) composite system at three different temperatures (70, 500 , and $1000^{\circ} \mathrm{F}$ ) to obtain an extensive profile of the thermal and mechanical properties.

In order to properly model a composite, the residual stresses generated by processing is included. To accomplish this, the cool-down history from consolidation temperature to room temperature $\left(70{ }^{\circ} \mathrm{F}\right)$ was simulated before the mechanical load was applied. For the high temperature cases $\left(500\right.$ and $\left.1000{ }^{\circ} \mathrm{F}\right)$, the load was applied after the heat-up from room temperature to service temperature. Due to the mismatch in the coefficient of thermal expansion (CTE), the stresses developed in the fiber were compressive while those developed in the matrix were tensile.

Table 3 presents the anticipated tangent properties of each composite. As predicted by METCAN, each composite's thermal and mechanical properties were evaluated at the test temperature after a small increment of load was applied. Material properties resulting from a compressive load will vary, but not significantly, from those listed in table 3. 
TABLE 3.-ANTICIPATED INITIAL THERMAL AND MECHANICAL PROPERTIES OF A UNIDIRECTIONAL COMPOSITE (0.30 FVR SiC/Ti6)

\begin{tabular}{|c|c|c|c|c|}
\hline \multirow{2}{*}{ Property } & \multirow{2}{*}{ Units } & \multicolumn{3}{|c|}{ Temperature in ${ }^{\circ} \mathbf{F}$} \\
\hline & & 70 & 500 & 1000 \\
\hline$\alpha_{111}$ & $\mathrm{ppm} / \mathrm{F}$ & 4.577 & 4.389 & 4.205 \\
\hline$\alpha_{122}$ & $\mathrm{ppm} / \mathrm{F}$ & 5.571 & 5.245 & 5.003 \\
\hline$\alpha_{133}$ & $\mathrm{ppm} / \mathrm{F}$ & 5.571 & 5.245 & 5.003 \\
\hline $\mathrm{C} 1$ & BTU/lb & 0.157 & 0.157 & 0.157 \\
\hline $\mathrm{K}_{111}$ & BTU/F-hr*in & 0.585 & 0.619 & 0.706 \\
\hline $\mathrm{K}_{122}$ & BTU/F-hr*in & 0.572 & 0.606 & 0.701 \\
\hline $\mathrm{K}_{133}$ & BTU/F-hr*in & 0.572 & 0.606 & 0.701 \\
\hline $\mathrm{E}_{111}$ & Mpsi & 26.676 & 25.606 & 23.618 \\
\hline $\mathrm{E}_{122}$ & Mpsi & 17.884 & 16.410 & 13.293 \\
\hline $\mathrm{K}_{133}$ & Mpsi & 17.884 & 16.410 & 13.293 \\
\hline $\mathrm{G}_{112}$ & Mpsi & 8.373 & 7.052 & 5.378 \\
\hline $\mathrm{G}_{123}$ & Mpsi & 7.227 & 6.750 & 5.586 \\
\hline $\mathrm{G}_{113}$ & Mpsi & 8.373 & 7.052 & 5.378 \\
\hline $\mathrm{S}_{111 \mathrm{~T}}$ & Ksi & 195.00 & 180.00 & 160.00 \\
\hline $\mathrm{S}_{111 \mathrm{C}}$ & Ksi & 193.05 & 178.20 & 158.40 \\
\hline $\mathrm{S}_{122 \mathrm{~T}}$ & Ksi & 64.75 & 50.75 & 35.00 \\
\hline $\mathrm{S}_{122 \mathrm{C}}$ & Ksi & 101.75 & 74.25 & 45.00 \\
\hline $\mathrm{S}_{112}$ & Ksi & 43.75 & 36.25 & 23.75 \\
\hline $\mathrm{S}_{123}$ & Ksi & 43.75 & 36.25 & 23.75 \\
\hline $\mathrm{S}_{113}$ & Ksi & 43.75 & 36.25 & 23.75 \\
\hline$v_{112}$ & in/in & 0.255 & 0.222 & 0.183 \\
\hline$v_{1123}$ & in in & 0.237 & 0.215 & 0.190 \\
\hline$v_{131}$ & in/in & 0.171 & 0.143 & 0.103 \\
\hline$\rho_{1}$ & lb/in**3 & 0.152 & 0.152 & 0.152 \\
\hline
\end{tabular}

Note: Properties obtained under initial tensile load. Strengths obtained from respective stress/strain curves.

The plots presented in figures 3 to 10 demonstrate METCAN's ability to capture the behavior of a metal matrix composite at varying temperatures for one fiber volume ratio. By using these plots as an initial guideline, it becomes clear that the behavior at various fiber volume ratios for different composites can be similarly simulated. It should also become clear that obtaining all this information by test will be time and cost prohibitive.

All the properties in figures 3 to 10 are plotted against longitudinal strain for commonality. The stress strain curve is plotted in figure 3 . Note the mild nonlinearity for almost the entire range. Note also the decrease with temperature. The longitudinal modulus is plotted in figure 4 . The discontinuities indicate local region (sector A in fig. 2) fractures. It is important to note these discontinuities are imperceptible in the stress-strain plots in figure 3. As can be seen, the modulus decreases continuously and exhibits an abrupt drop near composite fracture which occurs as a result of fiber fractures. 


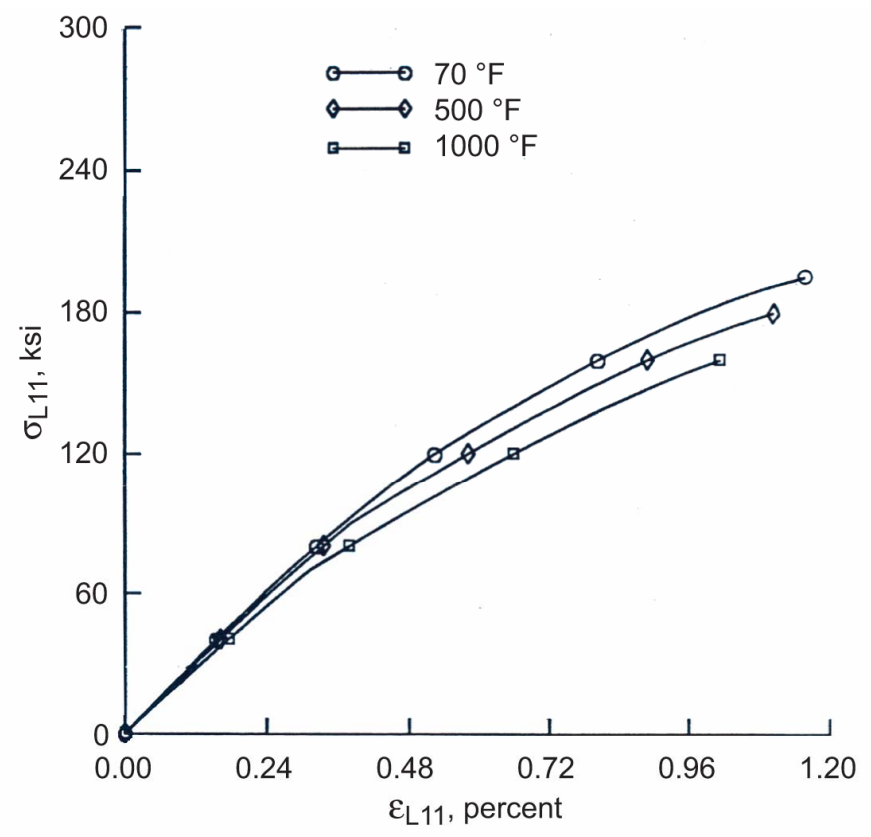

Figure 3.-Longitudinal load of $\mathrm{SiC} / \mathrm{Ti} 6$ at a fiber volume ratio of 0.30 : stress $\left(\sigma_{L 11}\right)$ vs. strain $\left(\varepsilon_{\mathrm{L} 11}\right)$ under temperature of 70 , 500 , and $1000^{\circ} \mathrm{F}$.

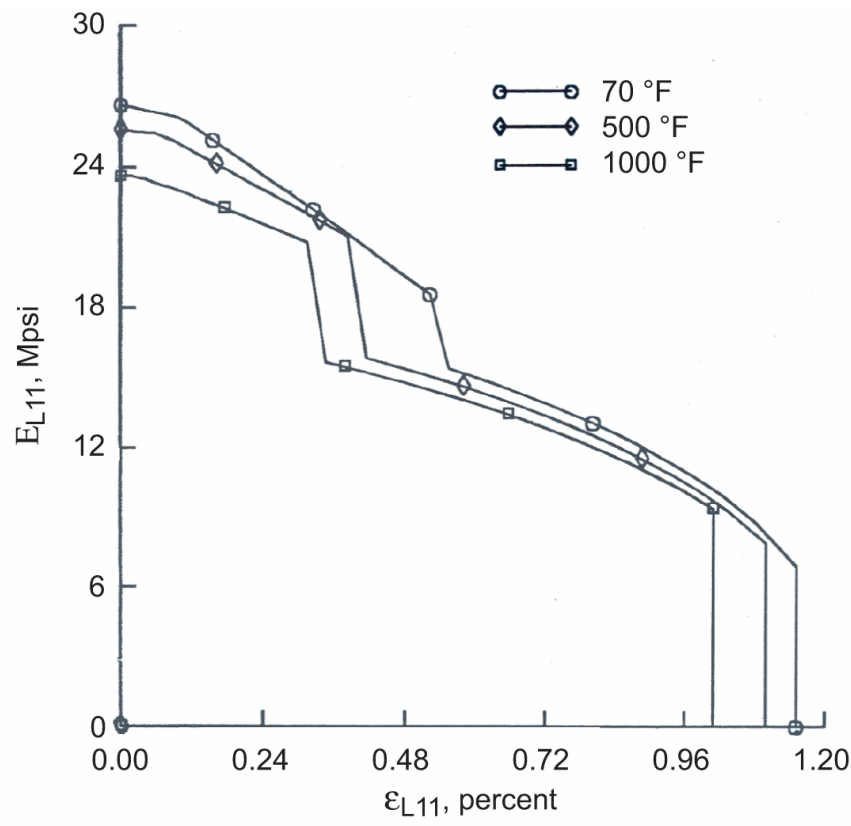

Figure 4.-Longitudinal load of $\mathrm{SiC} / \mathrm{Ti} 6$ at a fiber volume ratio of 0.30: elastic modulus $\left(\mathrm{E}_{\mathrm{L} 11}\right)$ vs. strain $\left(\varepsilon_{\mathrm{L} 11}\right)$ under temperature of 70,500 , and $1000^{\circ} \mathrm{F}$.

A comparable plot for the transverse modulus is shown in figure 5. Note the insensitivity of the transverse modulus with respect to longitudinal strain. The interpretation for this is that transverse local damage (cracks) has negligible effect on the transverse modulus when a unidirectional composite is loaded along the longitudinal (fiber) direction. Similarly for the in-plane shear modulus, $\mathrm{G}_{\ell 12}$ plotted versus longitudinal strain $\varepsilon_{\ell 11}$ in figure 6 . However, this is not the case when the composite is loaded in the transverse or in-plane shear. 


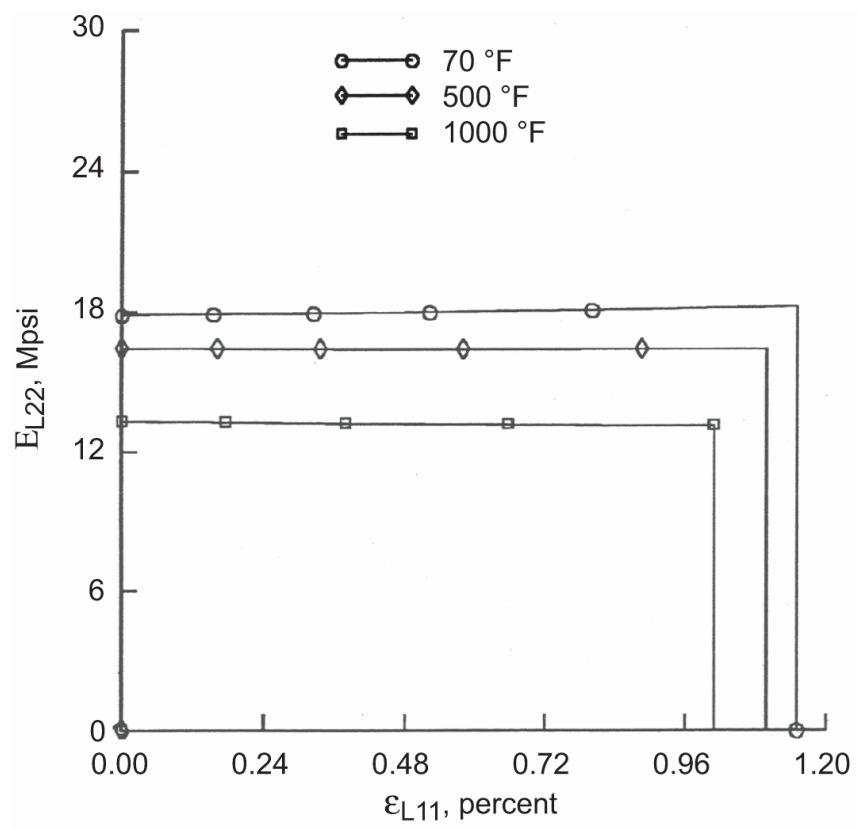

Figure 5.-Longitudinal load of $\mathrm{SiC} / \mathrm{Ti} 6$ at a fiber volume ratio of 0.30: elastic modulus $\left(\mathrm{E}_{\mathrm{L} 22}\right)$ vs. strain $\left(\varepsilon_{\mathrm{L} 11}\right)$ under temperature of 70,500 , and $1000^{\circ} \mathrm{F}$.

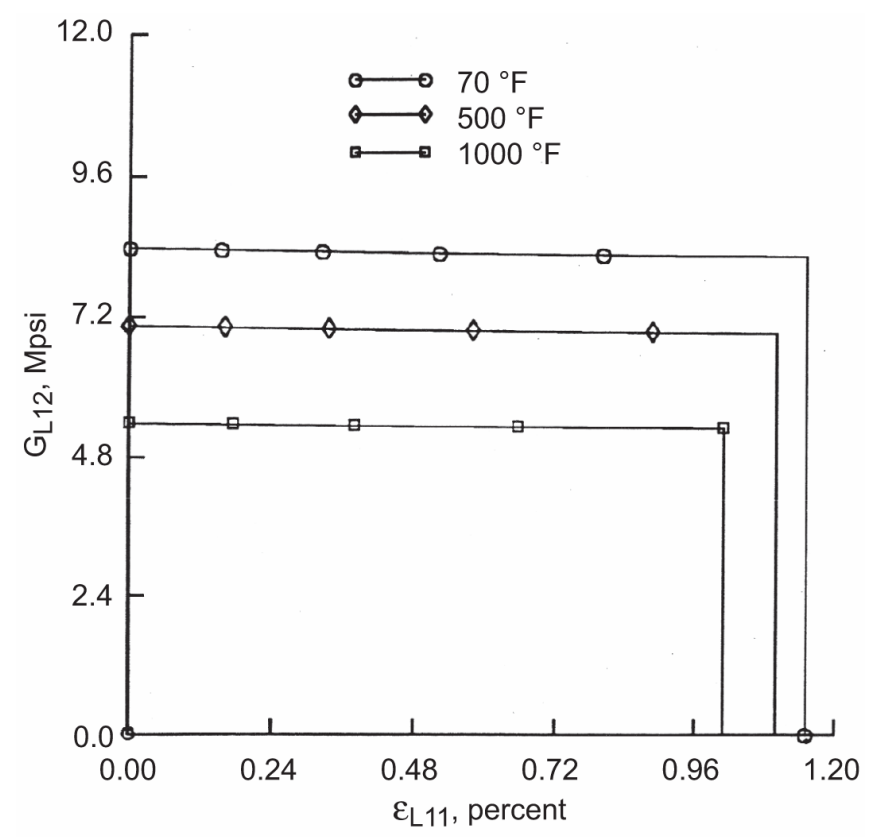

Figure 6.-Longitudinal load of $\mathrm{SiC} / \mathrm{Ti} 6$ at a fiber volume ratio of 0.30 : shear modulus $\left(G_{L 12}\right)$ vs. strain $\left(\varepsilon_{\mathrm{L} 11}\right)$ under temperature of 70,500 , and $1000^{\circ} \mathrm{F}$.

The in-plane major Poisson's ratio $v_{\ell 12}$ is plotted versus $\varepsilon_{\ell 11}$ in figure 7. As can be observed, $v_{\ell 12}$ is not sensitive to $\varepsilon_{\ell 11}$ which is comparable to $\mathrm{E}_{\ell 22}$ and $\mathrm{G}_{\ell 12}$ and for the same reasons that were mentioned. A different situation arises when the through-the-thickness $v_{\ell 32}$ is plotted versus $\varepsilon_{\ell 11}$. The results are displayed in figure 8 . Note that the magnitude increases continuously with discontinuous "jumps" in the region $0.3 \leq \varepsilon_{\ell 11} \leq 0.5$. These discontinuous jumps coincide with those in the longitudinal modulus in figure 4. Note also the rapid increase near the fracture region and almost instantaneous drop at fracture. 
The reasons for this behavior are the same as previously mentioned. The conclusion from this discussion is that local directional damage may be present that may be detected by some properties and may be insensitive to others. The graphical results described thus far demonstrate that generalizations should be avoided when interpreting test results from these complex composites tested at high temperatures.

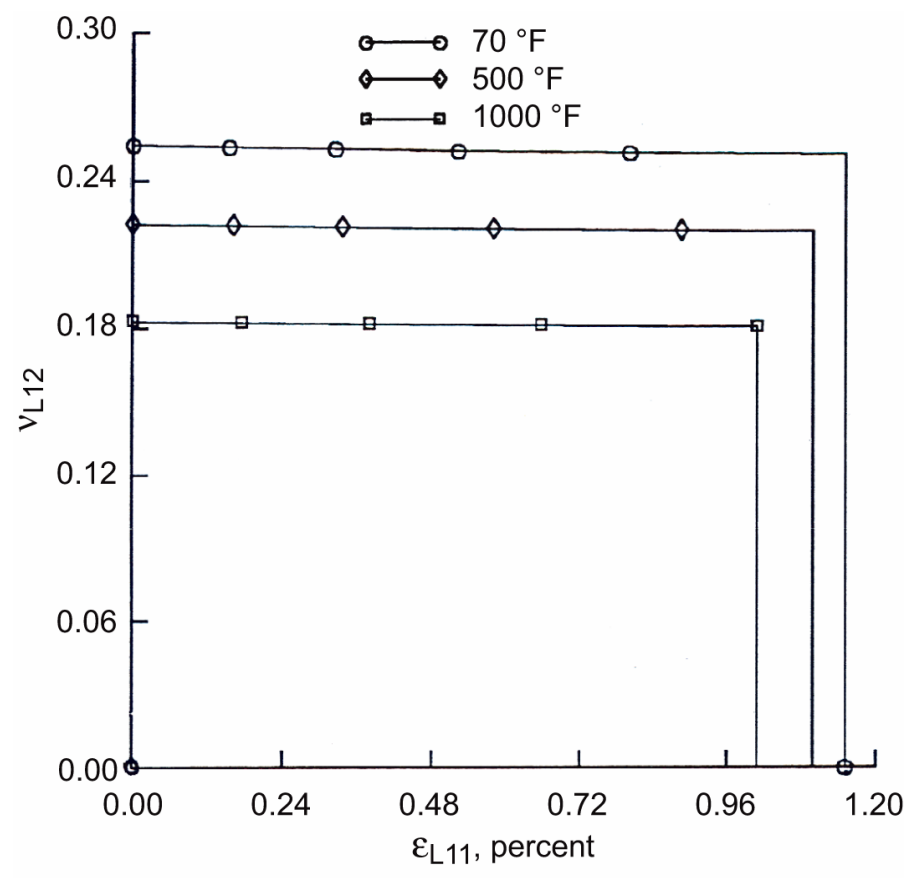

Figure 7.-Longitudinal load of $\mathrm{SiC} / \mathrm{Ti} 6$ at a fiber volume ratio of 0.30 : Poisson's ratio $\left(v_{\mathrm{L} 12}\right)$ vs. strain $\left(\varepsilon_{\mathrm{L} 11}\right)$ under temperature of 70,500 , and $1000^{\circ} \mathrm{F}$.

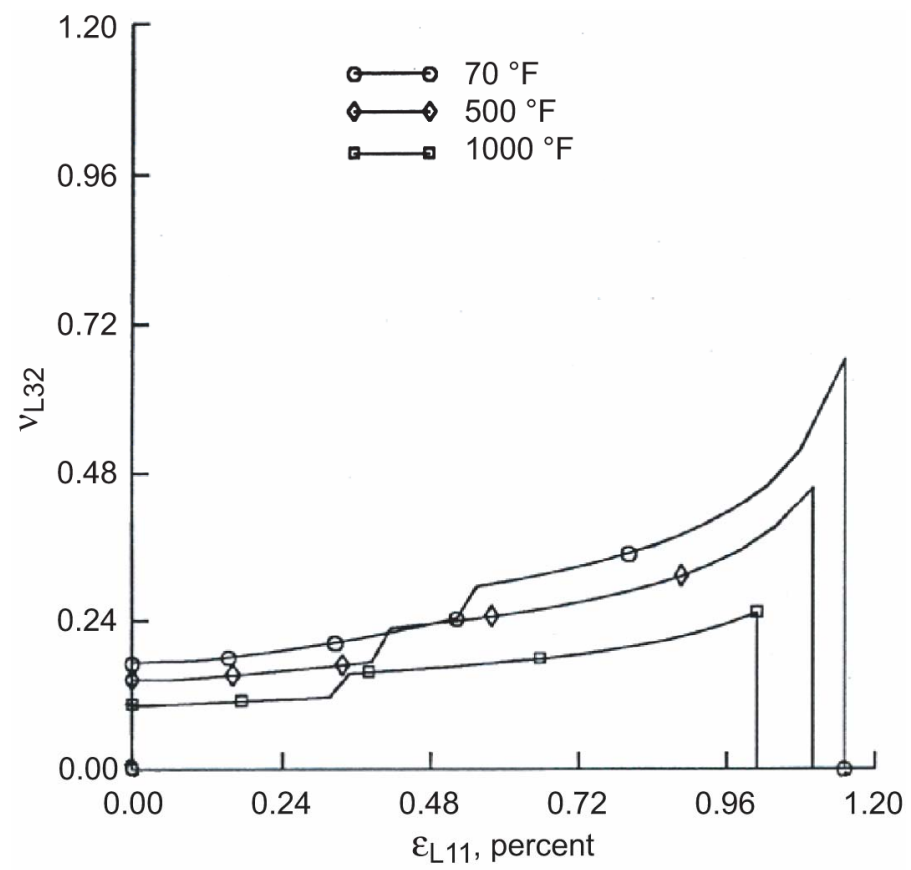

Figure 8.- - Longitudinal load of $\mathrm{SiC} / \mathrm{Ti} 6$ at a fiber volume ratio of 0.30: Poisson's ratio $\left(v_{\mathrm{L} 32}\right)$ vs. strain $\left(\varepsilon_{\mathrm{L} 11}\right)$ under temperature of 70,500 , and $1000^{\circ} \mathrm{F}$. 
The longitudinal thermal expansion coefficient $\alpha_{\ell 11}$ is plotted versus longitudinal strain in figure 9 . The curves increase nonlinearly up to the local longitudinal damage exhibited by the instantaneous discontinuity drop. Thereafter remain insensitive till fracture. The important point to be made from the results in figure 9 is that longitudinal thermal expansion monitoring during loading may be a sensitive test to identify local damage in these types of composites. Comparable results for longitudinal thermal conductivity $\mathrm{K}_{\ell 11}$ are shown in figure 10 . The behavior for $\mathrm{K}_{\ell 11}$ is more pronounced than that for $\alpha_{\ell 11}$. However, the interpretation and point to be made are similar to those made for $\alpha_{\ell 11}$.

Time dependent (rupture strength) behavior can be simulated by activating the time factor in the MFIM, which is the last term in the MFIM in figure 2. The combined thermal time effects can be simulated by activating the temperature and time factors (first and last terms, figure 2) simultaneously. The combined results obtained for a monolithic super alloy are shown in figure 11. Also, two experimental available points are plotted for comparison. The important point to be noted is that information for preliminary designs or early assessments can be generated for emerging or projected materials for specific applications. Comparable information can be generated for fatigue endurance. This is obtained by activating the mechanical fatigue factor (sixth term) in the equation in figure 2 . These results are plotted in figure 12 . Note the relatively rapid drop at small cyclic ratios and the leveling as the cyclic ratio increases. Fatigue resistance for composites has been also evaluated as reported in references 5 and 6 . Probabilistic fatigue in composites is described in references 7 and 8.

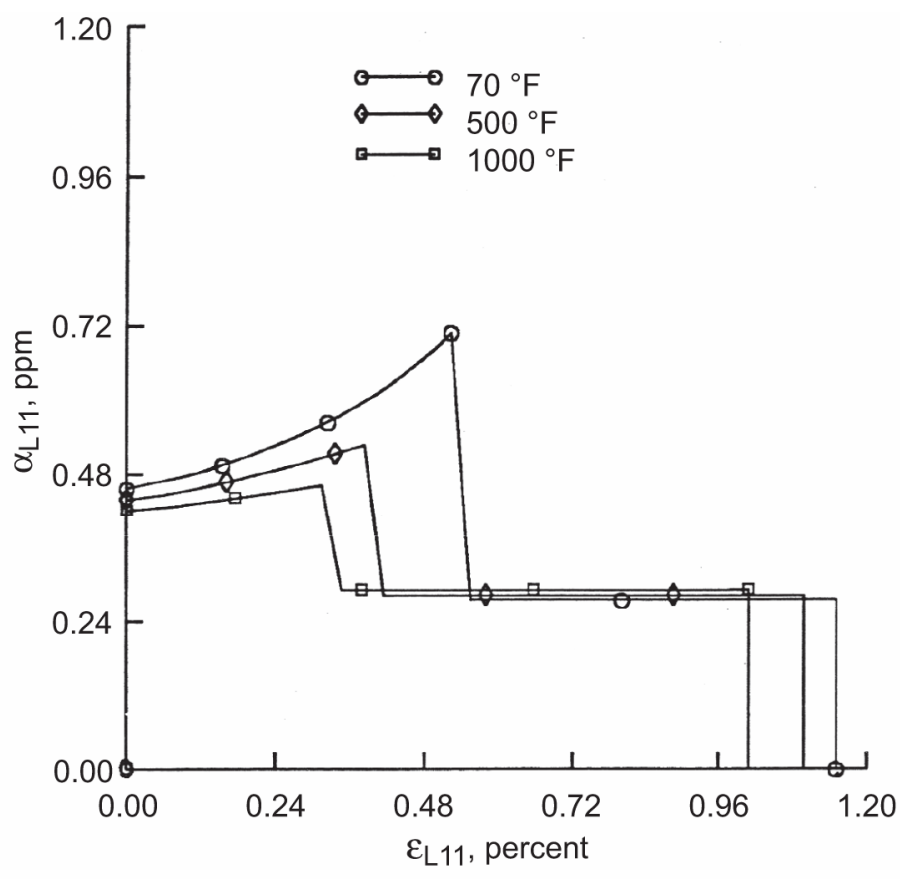

Figure 9.-Longitudinal load of $\mathrm{SiC} / \mathrm{Ti} 6$ at a fiber volume ratio of 0.30 : thermal expansion coefficient $\left(\alpha_{\mathrm{L} 11}\right)$ vs. strain $\left(\varepsilon_{\mathrm{L} 11}\right)$ under temperature of 70,500 , and $1000^{\circ} \mathrm{F}$. 


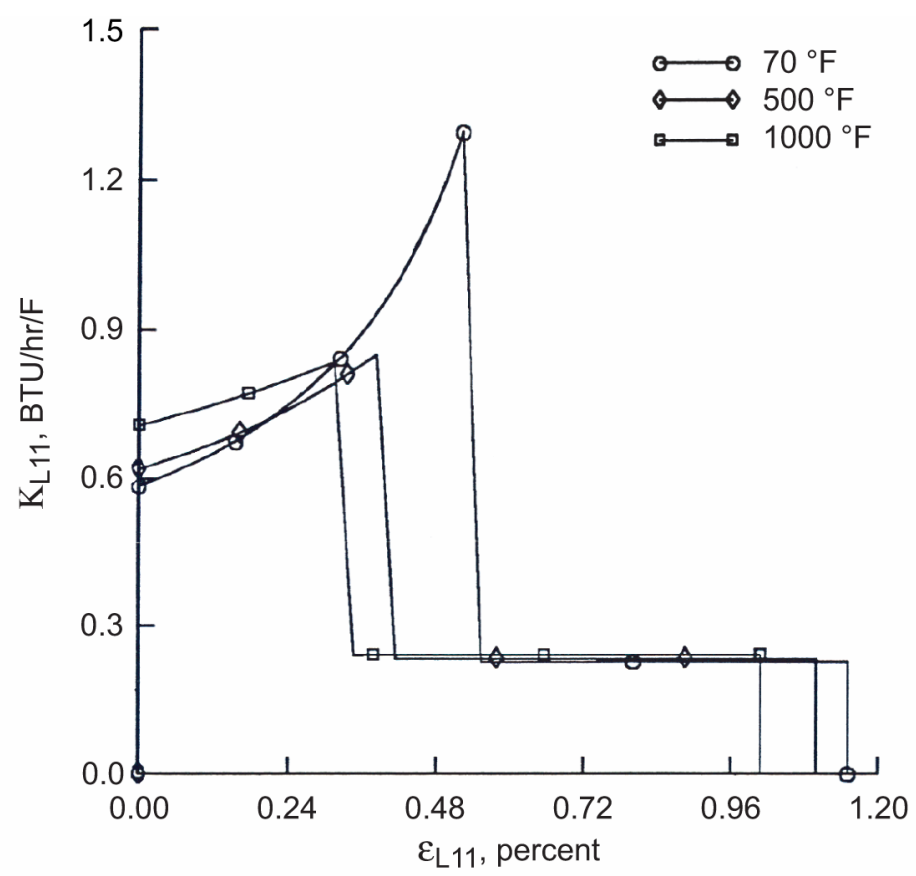

Figure 10.- Longitudinal load of $\mathrm{SiC} / \mathrm{Ti} 6$ at a fiber volume ratio of 0.30 : thermal conductivity $\left(\mathrm{K}_{\mathrm{L} 11}\right)$ vs. strain $\left(\varepsilon_{\mathrm{L} 11}\right)$ under temperature of 70,500 , and $1000^{\circ} \mathrm{F}$.

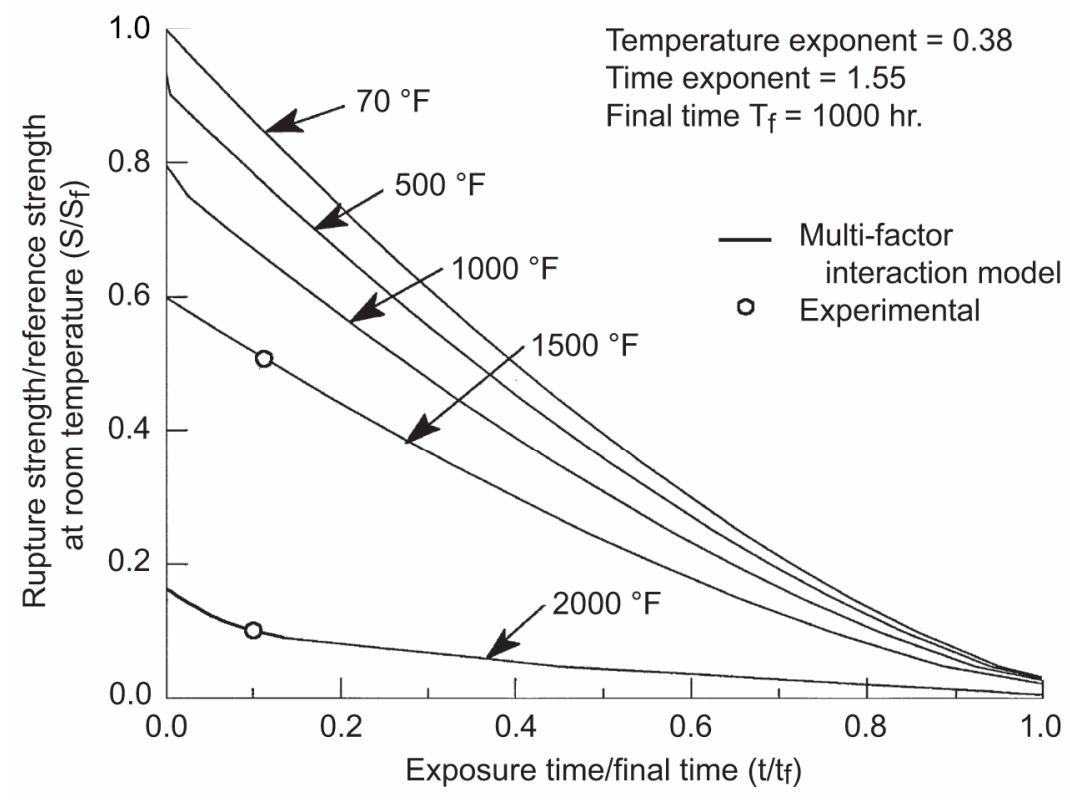

Figure 11.-Nickel base alloy B-1900 rupture strength at various temperatures (sustained stress $=90 \%$ of static strength). 


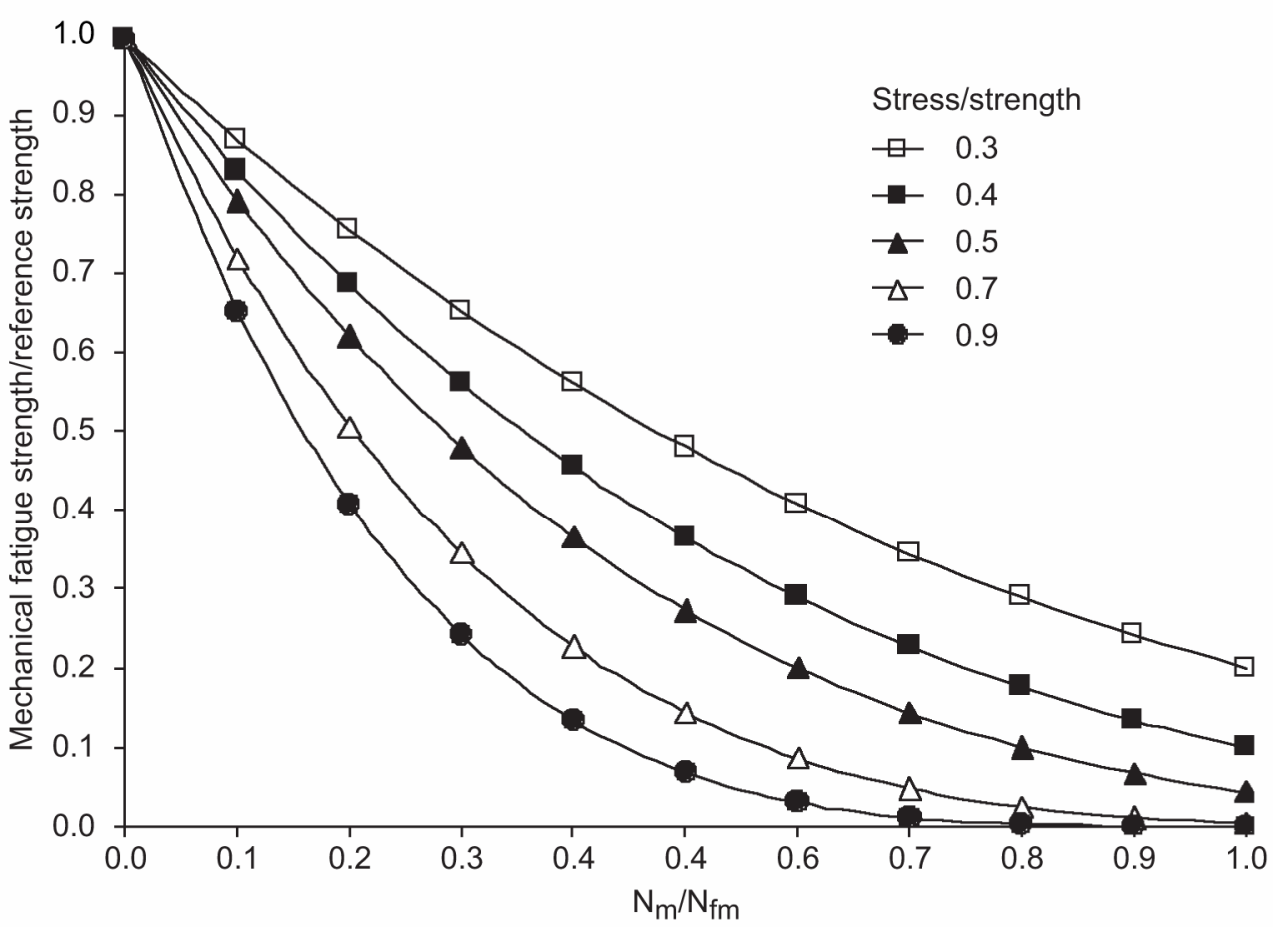

Figure 12.-Prediction of nickel alloy mechanical fatigue strength using the multi-factor interaction model (mechanical cycling effect, exponent $=4.5$ ).

The major observations from the above discussion are that: (1) The highest laminate strength is along the fiber direction; (2) The room temperature laminate transverse and shear strengths decrease substantially with temperature. The decreases are about 18 percent for the longitudinal tensile strength and about 55 percent for the transverse and shear strengths. Of lesser significance are the observations that: (1) The thermal expansion coefficient and the thermal conductivity indicate abrupt changes in regions where one or both constituents failed. These sharp drops correspond to a somewhat imperceptible change in the slope of the stress-strain plot in figure 3.

\section{Concluding Remarks}

The evaluation presents simulated (METCAN generated) results at temperatures of 70, 500, and $1000{ }^{\circ} \mathrm{F}$ for SiC/Ti6 at a fiber volume ratio of 0.30. It includes the following: (1) Table of Anticipated Thermal and Mechanical Properties, (2) Stress-Strain Curves, (3) Thermal Conductivities, (4) Thermal Expansions, (5) Elastic and Shear Moduli, and (6) Poisson's Ratios. It also includes simulated results for stress rupture and fatigue resistance of a high temperature super alloy. It is noted that the method is general and applicable to all types of composites, loading conditions, and service environments.

Some general trends are:

- The highest ultimate tensile strength (UTS) is along the fiber. The room temperature transverse and shear strengths are roughly one third and one fourth, respectively, of the longitudinal UTS. Temperature causes these two strengths to degrade by approximately 55 percent while the longitudinal strength degrades by only 18 percent.

- Some of the curves for the coefficient of thermal expansion (CTE $\alpha$ ) and thermal conductivity (K) indicate abrupt changes in regions where one or both of the constituents failed. These sharp drops 
correspond to a sometimes imperceptible change in the slope of the stress-strain plot. When a failure of this type occurs, the mechanism for heat transfer is disrupted.

- The elastic (E) and shear (G) moduli experience a moderate degradation due to increasing temperature. The highest modulus is along the fiber (26 Mpsi). The transverse moduli are somewhat less (18 Mpsi) while the shear moduli are much smaller (8 Mpsi).

- The major Poisson's ratio remains about constant as temperature and longitudinal strain increase. The through-the-thickness Poisson's ratio increases nonlinearly with increasing strain and temperature, which is reflected in the behavior of the corresponding decreases in the longitudinal modulus.

- The rupture strength of a high temperature super alloy decreases rapidly with exposure time and with exposure temperature. The major decrease is from 1500 to $2000{ }^{\circ} \mathrm{F}$ because $2000{ }^{\circ} \mathrm{F}$ is approaching the melting temperature of the matrix.

- The fatigue strength of the super alloy decreases rapidly at low cyclic ratios and decreases somewhat slower as the cyclic ratio increases.

- The collective results demonstrate the versatility and effectiveness of multi level computational simulation coupled with a multi factor interaction model.

\section{References}

1. Hopkins, D.A. and Murthy, P.L.N.: METCAN—The Metal Matrix Composite Analyzer.

NASA CP 3003, vol. 2, 1988.

2. Chamis, C.C. and Minnetyan, L.: A Multi-Factor Interaction Model (MFIM) for Damage Initiation and Progressions. Presented in the Session on Damage Initiation and Prediction in Composites at the 2001 ASME International Mechanical Engineering Congress and Exposition (IMECE), New York, NY, November 11-16, 2001.

3. Hopkins, D.A.: Nonlinear Analysis of High Temperature Multilayered Fiber Composite Structures. NASA TM 83754, 1984.

4. Lee, H.J., Murthy, P.L.N., and Chamis, C.C.: METCAN Updates for High Temperature Composite Behavior: Simulation/Verification. NASA TM 103682, 1991.

5. Chamis, C.C., Murthy, P.L.N., and Hopkins, D.A.: Computational simulation of High Temperature Metal Matrix Composites Cyclic Behavior. NASA TM 102115, 1988.

6. Minnetyan, L., Abdi, F., and Chamis, C.C.: Cyclic Fatigue Damage Evolution in Airfoil Structures, 46th International SAMPE Symposium, vol. 46, Book 1 of 2, pp. 1037-1048, May 5-10, 2001.

7. Minnetyan, L., Chamis, C.C., Abdi, F., and Huang. D.: Probabilistic Cyclic Fatigue of Composite Structures, 42nd AIAA/ASME/ASCE/AHS/ASC Structures, Structural Dynamics and Materials Conference, Seattle, WA, No. AIAA-2001-1375, pp. 1-7, April 16-19, 2001.

8. Minnetyan, L., Huang, D., and Chamis, C.C.: Probabilistic Fatigue Life Evaluation of Composite Structures, 46th International SAMPE Symposium, vol. 46, Book 1 of 2, pp. 985-994, May 6-10, 2001. 


\section{Appendix — Symbols List}

$\mathrm{C}=$ Heat Capacity (BTU/Ib)

$\mathrm{E}=$ Normal Modulus (Mpsi)

$\mathrm{G}=$ Shear Modulus (Mpsi)

$\mathrm{K}=$ Thermal Conductivity (BTU $/{ }^{\circ} \mathrm{F} * \mathrm{hr} *$ in)

$\mathrm{S}=$ Strength (Ksi)

$\alpha=$ Coefficient of Thermal Expansion $\left(\mathrm{ppm} /{ }^{\circ} \mathrm{F}\right)$

$\varepsilon=$ Strain (in/in \%)

$v=$ Poisson's Ratio (in/in)

$\rho=$ Density $\left(\mathrm{lb} / \mathrm{in}^{3}\right)$

\section{Subscripts}

$\ell=$ L Ply Related Quantity

$\mathrm{T}, \mathrm{C}=$ Tension, Compression

$1,2,3=$ Material Coordinate System Axes

CONVERSION FACTORS

\begin{tabular}{|c|c|c|c|}
\hline Property & English Units & Multiply By & SI Units \\
\hline $\begin{array}{c}\text { Modulus, } \\
(\text { G\&E) }\end{array}$ & Mpsi & 6.89 & $\mathrm{GPa}$ \\
\hline $\begin{array}{c}\text { Strength, } \\
(\mathrm{S})\end{array}$ & $\mathrm{Ksi}$ & 6.89 & $\mathrm{MPa}$ \\
\hline $\begin{array}{c}\text { Thermal Conductivity, } \\
(\mathrm{K})\end{array}$ & $\mathrm{BTU} /{ }^{\circ} \mathrm{F}^{*} \mathrm{hr}{ }^{*}$ in & 6.94 & $\mathrm{WJ} / \mathrm{m}-{ }^{\circ} \mathrm{K}$ \\
\hline $\begin{array}{c}\text { Heat Capacity, } \\
(\mathrm{C})\end{array}$ & $\mathrm{BTU} / \mathrm{Ib}$ & 2.326 & $\mathrm{~mm} / \mathrm{mm} \mathrm{K}$ \\
\hline $\begin{array}{c}\text { CTE, } \\
(\alpha)\end{array}$ & $\mathrm{ppm} /{ }^{\circ} \mathrm{F}$ & $1.8 \times 10^{-6}$ & $\mathrm{~g} / \mathrm{cm}^{3}$ \\
\hline $\begin{array}{c}\text { Density, } \\
(\rho)\end{array}$ & $1 \mathrm{~b} / \mathrm{in}^{3}$ & 27.7 & \\
\hline
\end{tabular}


Public reporting burden for this collection of information is estimated to average 1 hour per response, including the time for reviewing instructions, searching existing data sources, gathering and maintaining the data needed, and completing and reviewing the collection of information. Send comments regarding this burden estimate or any other aspect of this collection of information, including suggestions for reducing this burden, to Washington Headquarters Services, Directorate for Information Operations and Reports, 1215 Jefferson Davis Highway, Suite 1204, Arlington, VA 22202-4302, and to the Office of Management and Budget, Paperwork Reduction Project (0704-0188), Washington, DC 20503.

\begin{tabular}{|l|l|l|}
\hline 1. AGENCY USE ONLY (Leave blank) & $\begin{array}{c}\text { 2. REPORT DATE } \\
\text { February } 2006\end{array}$ & $\begin{array}{r}\text { 3. REPORT TYPE AND DATES COVERED } \\
\text { Technical Memorandum }\end{array}$
\end{tabular}

4. TITLE AND SUBTITLE 5. FUNDING NUMBERS

Simulated Data for High Temperature Composite Design

6. AUTHOR(S)

WBS 984754.02.07.03

Christos C. Chamis and Galib H. Abumeri

7. PERFORMING ORGANIZATION NAME(S) AND ADDRESS(ES)

National Aeronautics and Space Administration

John H. Glenn Research Center at Lewis Field

Cleveland, Ohio 44135-3191

8. PERFORMING ORGANIZATION REPORT NUMBER

E-15445

9. SPONSORING/MONITORING AGENCY NAME(S) AND ADDRESS(ES)

10. SPONSORING/MONITORING AGENCY REPORT NUMBER

National Aeronautics and Space Administration

Washington, DC 20546-0001

NASA TM-2006-214111

11. SUPPLEMENTARY NOTES

Christos C. Chamis, NASA Glenn Research Center; and Galib H. Abumeri, QSS Group, Inc., 21000 Brookpark

Road, Cleveland, Ohio 44135. Responsible person, Christos C. Chamis, organization code R, 216-433-3252.

12a. DISTRIBUTION/AVAILABILITY STATEMENT

12b. DISTRIBUTION CODE

Unclassified - Unlimited

Subject Category: 24

Available electronically at http://gltrs.grc.nasa.gov

This publication is available from the NASA Center for AeroSpace Information, 301-621-0390.

13. ABSTRACT (Maximum 200 words)

The paper describes an effective formal method that can be used to simulate design properties for composites that is inclusive of all the effects that influence those properties. This effective simulation method is integrated computer codes that include composite micromechanics, composite macromechanics, laminate theory, structural analysis, and multi-factor interaction model. Demonstration of the method includes sample examples for static, thermal, and fracture reliability for a unidirectional metal matrix composite as well as rupture strength and fatigue strength for a high temperature super alloy. Typical results obtained for a unidirectional composite show that the thermal properties are more sensitive to internal local damage, the longitudinal properties degrade slowly with temperature, the transverse and shear properties degrade rapidly with temperature as do rupture strength and fatigue strength for super alloys.

\section{SUBJECT TERMS}

Composites; High temperature; Design properties; Mechanical; Thermal; Static;

Rupture; Fatigue

17. SECURITY CLASSIFICATION OF REPORT

Unclassified
18. SECURITY CLASSIFICATION OF THIS PAGE

Unclassified
19. SECURITY CLASSIFICATION OF ABSTRACT

Unclassified
15. NUMBER OF PAGES

19

16. PRICE CODE

20. LIMITATION OF ABSTRACT

Standard Form 298 (Rev. 2-89)

Prescribed by ANSI Std. Z39-18 298-102 

